\title{
Kurtların (Canis lupus) Batı Karadeniz Bölgesi’ndeki habitat tercihleri ve habitatlarının yönetilmesi için öneriler
}

\author{
Ferhat TOKMAK (Orcid: 0000-0003-2690-8618) ${ }^{1}$, Hüseyin AMBARLI (Orcid: 0000-0003-4336-9417) ${ }^{{ }^{*}}$ \\ 'Düzce Üniversitesi, Orman Fakültesi, DÜZCE \\ "Sorumlu yazar/Corresponding author: huseyinambarli@duzce.edu.tr, Geliş tarihi/Received: 17.04.2018, Kabul tarihi/Accepted: 28.05.2018
}

$\ddot{O} \mathbf{z}$

Kurtlar Türkiye'nin bütün bölgelerinde dağılım göstermektedir. Bununla birlikte ülkemizde kurtlara dair yapılmış çalışma sayısı oldukça sınırlıdır. Bu çalışma, insan etkisinin ve orman varlığının yoğun olduğu Bolu Orman Bölge Müdürlüğü alanı içerisinde Düzce ve Bolu illerinde, kurtların habitat kullanımlarını ve tercihlerini tespit etmek için yapılmıştır. Elde edilen veriler 1şı̆̆ında da kurtların yönetimi için bazı öneriler getirilmiştir. Arazi çalışmalarında kurtların varlığı, rastgele seçilen örnekleme alanlarında dışkı tespiti ve fotokapan çalışmasına dayanarak tespit edilmiştir. Veriler analiz edilmeden önce oto korelasyonu önlemek için benzer verilerin bir kısmı veri grubundan çıkarılmıştır. Toplam olarak 48 adet kurt varlığı tespit edilmiştir. Ayrıca habitat varlığının tespiti için rastgele 48 nokta seçilmiş ve bu alanlara ait habitat bilgileri de kurtların habitat kullanımı ve tercih analizlerinde kullanılmıştır. ArcGIS programı kullanılarak her iki 48 noktanın etrafında 2,5 km tampon bölge oluşturulmuş ve bölge içinde kalan meşçere tiplerinin alanları hesaplanmıştır. Bunlar daha sonra beş habitat sınıfına indirgenmiş ve alanların kurtlar tarafından kullanılıp kullanılmadığı ve seçim oranı (w) hesaplanmıştır. Ayrıca her iki örnekleme alanına ait veri seti birbirleriyle eğim, bakı, yükseklik, yola ve yerleşim yerlerine uzaklık açısından değerlendirilerek t-testiyle test edilmiş, $\mathrm{p}<0,05$ için birbirlerinden anlamlı bir farkı olup olmadığı hesaplanmıştır. Çalışmamızda kurtlar genellikle $1.100 \mathrm{~m}$ üzerinde, ibreli ormanları ve 50 dereceden daha yüksek eğimli kuzey bakıları ve özellikle insan etkisinden uzak alanlarda bulunmayı tercih etmektedir. Kurtların yoğun insan faaliyetlerinin olduğu alanlardan örneğin ormancılık faaliyetleri ve otoyollardaki trafikli bölgelerden çekindikleri tespit edilmiştir. Ek olarak, kurtların habitatlarının daha detaylı analiz edilebilmesi için modern radyo telemetri yöntemleriyle izlenmesi ve diyetinin tespit edilmesinin faydalı olacağı düşünülmektedir.

Anahtar kelimeler: kurt, etçiller, kaynak kullanımı, habitat, Düzce, Bolu

\section{Habitat preferences of wolves (Canis lupus) in western Black Sea Region and suggestions for the management of habitats}

\begin{abstract}
Wolves are distributed in all regions of Turkey, but there is a very limited number of studies about wolves. This study was conducted to determine habitat use and preferences of wolves in Düzce and Bolu provinces within Bolu Forest Regional Directorate where human disturbance and forest existence are intense. Some suggestions were made for the management of wolves. Presence of wolves was recorded by using randomly founded scats in the field, and wolf photographs in camera traps. Before analyzing the existing data, similar locations were removed to prevent autocorrelation. A total of 48 wolf occurrences were determined. In addition, 48 randomly chosen points corresponding to the existing habitat specifications were used to analyze habitat use and preference. Of $2.5 \mathrm{~km}$ buffer was drawn to both 48 points using the ArcGIS program, and the areas of forest stands were calculated. These were then reduced to five habitat classes, and the habitat preference rate $(\mathrm{w})$ and usage of wolves were calculated by using the ratio of these two areas. In addition, these two data sets were analyzed with respect to slope, elevation, distance to the roads and settlements by statistical t-test. Besides, it was calculated whether there is a significant difference for $\mathrm{p}<0.05$. As a result, we found that wolves generally were over $1100 \mathrm{~m}$ above sea level in coniferous forests with less human influence, and preferred northern aspects with more than 50 degrees in slope. We revealed that wolves avoid from heavy traffic at highways and cutting-based forestry activities in the forests. To analyze the habitats in detail, it can be useful to monitor wolves by using modern radio telemetry methods and to analyze the diet of wolves.
\end{abstract}

Keywords: wolf, carnivores, resource use, habitat, Düzce, Bolu

To cite this article (Atıf): TOKMAK, F, AMBARLI, H. (2018). Kurtların (Canis lupus) Batı Karadeniz Bölgesi'ndeki habitat tercihleri ve habitatlarının yönetilmesi için öneriler. Ormancılık Araştırma Dergisi, 5(2), 169-175.

DOI: https://doi.org/10.17568/ogmoad.416026 


\section{Giriş}

Karnivorlar, ekosistemlerin doğal işleyişlerinde önemli roller üstlenmektedirler (Mech, 1996). Karnivora takımının Canidae familyasın bir türü olan kurt (Canis lupus Linnaeus, 1758) bulunduğu ortama son derece iyi uyum sağlayabilmesi ve fark11 beslenme davranışı gösterebilmeleri nedeniyle (Mech ve Boitani, 2003) Türkiye'de yoğunlukla İç Anadolu ve Doğu Anadolu Bölgesi başta olmak üzere bütün bölgelerde yaklaşık olarak 500.000 $\mathrm{km}^{2}$ bir alanda yayılış göstermektedir (Ambarlı ve ark., 2016).

Avrupa'da yapılan birçok çalışmaya göre kurtlar habitat olarak orman örtüsü ile kaplı alanları daha fazla kullanmaktadırlar (Jedrzejwski ve ark., 2004; Zlatanova ve Popova, 2013; Kuzyk ve ark., 2004) ve asıl besin kaynakları yaban domuzu ve geyiklerdir (Buzbaş, 2002; Wagner ve ark., 2012). Ülkemizde hayvancılığa bağlı olarak doğrudan kurtlar üzerinde veya yaşam alanlarında artan yoğun insan baskısı nedeniyle geçmişte kurtların populasyon büyüklüklerinde azalmalar meydana gelmiştir (Can, 2001). Günümüzde de yoğun habitat tahribatı ve kurtların potansiyel besin kaynaklarının kaçak veya aşırı avcılık sebebiyle azalması kurt-insan çatışmalarının artmasına, bu da hem kurtların hem insanların zarar görmesine neden olmaktadır (Ambarlı ve ark., 2016). Kurtlar Türkiye'de IUCN'nin belirlediği “Düşük Riskli” kategorisinde bulunmaktadır ancak 4915 sayılı Kara Avcılığ1 Kanununa göre koruma altındadır ve ürünlere zarar veren bireyler dışında avlanmaları yasaktır. Kurtlarla ilgili farklı ülkelerde yapılan çalışma örneklerinde birçok araştırmacı tarafından kurtların dağılım ve bolluğu (Zlatonova ve Popova, 2013), yapılan ormancılık faaliyetlerinin kurtlar üzerine olan etkisi (Kuzyk ve ark., 2004), coğrafi bilgi sistemleri (CBS) tabanlı analizler yaparak kurtların habitat tercihleri (Milakoviç ve ark., 2011) ve uydu vericili tasma sistemi yardımıyla habitatları (McLoughlin ve ark., 2004) belirlenmiştir. Ülkemizde ise; kurtların geçmişte Türkiye'deki durumu Can (2001), Konya'da kurt-insan çatışması Tuğ (2005), CBS tabanlı analizler kullanarak kurtların habitat uygunluk ve yayılış modeli Ertürk (2010) ve Türkiye'de kurtların genel dağılımları, populasyon büyüklükleri, insan-kurt çatışmasının nedenleri ve olası çözüm yolları Ambarlı ve ark. (2016) tarafından çalışılmıştır. Kurtların diyeti konusunda ise Doğu Trakya yöresinde Buzbaş (2002) ve Sarıkamış’ta çöplük yakınlarından beslenen kurtlar üzerine Capitani ve ark., (2015) tarafından yapılan sınırlı çalışmalar bulunmaktadır. Ayrıca kurtların alansal ekolojisi ve mevcut populasyon yapısı Ertürk (2017) tarafından araştırılmıştır.
Yaban hayvanlarının korunması ve geliştirilmesi onların ekolojilerini ve habitat tercihlerini iyi bilmekten geçmektedir (Oğurlu, 2001). Bu çalışma, Kuzeybatı Anadolu'da Bolu ve Düzce ili gibi yoğun orman varlığ1 olan (Şekil 1), aynı zamanda yoğun insan faaliyeti bulunan ve ortasından Türkiye'nin en işlek otoyol (E80) ve devlet yolunun (D100) geçtiği yerlerde kurtların habitatlarını ekolojik ve çevresel parametrelere göre nasıl seçtiğini ortaya koymayı amaçlamaktadır. Çünkü bu alanlarda menfezler dışında hayvanların geçiş yapabilmesi için kullanabileceği ekolojik köprüler henüz bulunmamaktadır. Bu konuda OGM ve Batı Karadeniz Ormancılık Araştırma Enstitüsü Müdürlüğünün yürütmekte olduğu "Bolu İlinde Yolların ve Trafiğin Büyük Memeliler Üzerine Etkisi” adlı proje devam etmektedir. Ayrıca bu çalışmada insan faaliyetlerinin kurtların habitat kullanımı üzerindeki olası etkilerini ortaya koymak ve yapılacak olan tür veya orman amenajman planlarına öneriler sunmak amaçlanmıştır.

\section{Materyal ve Yöntem}

\section{1. Çalışma alanı}

Çalışma alanı Batı Karadeniz Bölgesi’nde yer alan Düzce ve Bolu illerini kapsamaktadır (Şekil 1). Düzce ili coğrafi konumu $40,843849 \mathrm{~K}$ enlemi ve 31,15654 D boylamı arasındadır. Toplam yüzölçümü $3641 \mathrm{~km}^{2}$ dir. Ortalama yükselti 240 $\mathrm{m}$ ve merkez ilçe rakımı $153 \mathrm{~m}$ civarındadır. Ortalama sıcaklığı $13,3{ }^{\circ} \mathrm{C}$ ve ortalama yağış 825 mm'dir (Anonim, 2018a). Bolu ili coğrafi konumu 40,575977 K enlemi ve 31,578809 D boylamı arasındadır. Toplam yüz ölçümü $8323 \mathrm{~km}^{2}$ dir. Ortalama yükselti $1000 \mathrm{~m}$ ve merkez ilçe rakımı $725 \mathrm{~m}$ civarındadır. Yıllık ortalama sıcaklığ $10,5{ }^{\circ} \mathrm{C}$ ve yıllık ortalama yağış miktarı 545 mm'dir (Anonim, 2018b).

Çalışma alanı içerisinde bulunan orman varlığının \% 63'ü ibreli, \% 21'i yapraklı ve \% 16's1 ibreli ve yapraklı ormanların oluşturduğu karışık ormanlardan oluşmaktadır (Anonim, 2012).

\subsection{Yöntem}

Çalışma alanı içerisinde 300 ila 2500 metre yükseklikler arasında rastgele orman yollarında ortalama $30 \mathrm{~km}$ hızla 4x4 araçla gezilerek yaklaşık 350 $\mathrm{km}$ orman yolunda kurtların varlığına ilişkin iz ve diğer belirteçler Haziran-Aralık 2017 arasında kontrol edilmiştir. Arazi çalışmaları sırasında 80 adet kurt dışkısı tespit edilmiştir. Bu dışkıların bir kısmı aynı gruptan veya yakın yerlerden olduğu için oto korelasyonu önlemek için elenmiştir. Arazi çalışmasında tespit edilen kurt izleri $(n=1)$ ve bulu- 


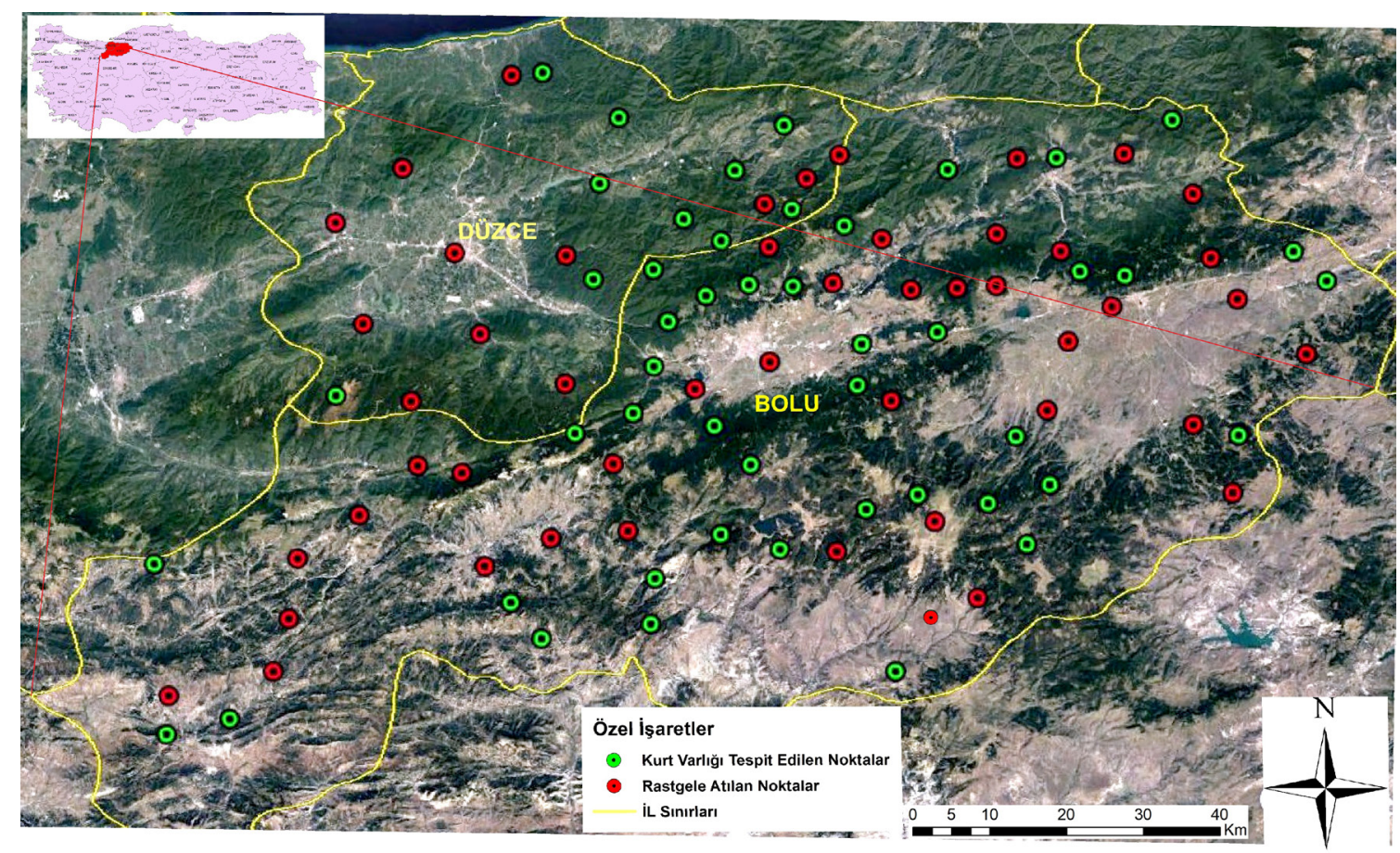

Şekil 1. Çalışma alanı ve kurtların bulunduğu noktalar ile rastgele noktaların gösterimi Figure 1. The area where the wolves exist and randomly chosen points

nan kurt dışkılarının ( $\mathrm{n}=10)$ konumları el konum belirleme cihazı (GPS) ile alınarak kaydedilmiştir. Ayrıca çalışma alanında daha önceden yapılmış olan araştırmalarda kurulan fotokapanlar ile kurt varlığ 1 tespit edilen noktalar (Keten, 2016) $(n=37)$ da dâhil olmak üzere toplam 48 farklı noktada kurt varlığı tespit edilmiștir. Bulunan bu noktalar çalışma alanında kurtların habitat tercihini belirlemek için kullanılmıştır.

Kurtların habitat seçimini belirlemek için kurt varlığ 1 tespit edilen $(\mathrm{n}=48)$ noktalar ArcMap 10.1 bilgisayar programına aktarılmıştır. Çalıșma alanı içerisine ArcMap 10.1 programında Hawths Tools eklentisi kullanılarak kurt varlığ 1 tespit edilen noktalarından farklı yerlere 48 adet rastgele noktalar (random points) oluşturulmuştur (Şekil 1). Rastgele atılan noktalar mevcut habitat tiplerini yansıtması açısından kullanılmıştır. Ayrıca mevcut vejetasyon tiplerini sınıflandırmak için Bolu ve Düzce'deki mevcut meşçere sınıfları ile rastgele noktalara denk gelen meşçere sınıfları da hesaplamalarda kullanılmıştır. Hayvanların habitat seçiminde, mevcut alanda bulunan habitat tiplerine göre hayvanların habitatları kullanım oranları, habitat tercihlerini belirleyecektir. Bu da kullanılan alanların büyüklüğünün veya yüzdesinin, mevcut alanların büyüklüğüne veya yüzdesine bölünmesiyle elde edilmektedir (Manly ve ark.,2002). Bu seçim veya tercih oranı "w" ile gösterilmektedir. Eğer seçim oranı (w) $>1$ ise türün bu alanı tercih et- tiği; eğer $(w)<1$ ise alandan çekindiği anlaşılmaktadır (Manly ve ark., 2002).

Bolu Orman Bölge Müdürlüğü'nden temin edilen meşçere haritaları üzerine kurt varlığı tespit edilen noktaların ve rastgele atılan noktaların merkezi referans alınarak dairesel olacak şekilde alan 2500 m (Merrill ve Mech, 2000) yarıçap uzunluğunda tampon bölge olușturulmuş; bununla bölge müdürlüğünün meşcere haritası çakıştırılmış ve habitat tipleri incelenmiştir. Toplamda 509 farklı meşçere tipi bulunmuş ve daha kolay anlaşılabilmesi için toplam meşçere tipleri 5 farklı habitat tipine indirgenmiştir. Bunlar; Yapraklı (meşe, kayın, gürgen, ceviz, kestane, kavak, çınar ve diğer); İbreli (sar1çam, karaçam, kızılçam, ladin, sedir, ardıç, göknar ve duglas); Karışık (ibreli + yapraklı); Ziraatİskân (ziraat ve iskân alanları); Orman İçi Açıklık

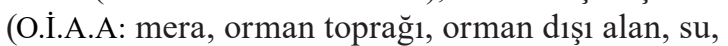
yol) olacak şekilde sınıflandırılmıştır.

Mevcut habitat olarak rastgele noktalara ait 2,5 km yarıçaplı daire içindeki tüm meşçere tipleri değerlendirilerek buraya ait habitat tiplerinin oranları belirlenmiştir. Bu ayrıca kurtların bulunduğu 2,5 km yarıçaplı daireler için de yapılarak kurtların bu habitatları kullanım oranları belirlenmiștir. Daha sonra bu iki değer Tablo 1'de gösterildiği üzere bölünerek seçim oranı hesaplanmıştır.

Herhangi bir hatayı da ortadan kaldırmak ve 
yaptığımız çalışmayı doğrulamak için de ayrıca rastgele noktalar yerine mevcut Bolu Orman Bölge Müdürlüğü'ne ait tüm meşçere sınıflarının oranları belirlenerek bunlar yukarıda tanımlanan habitat tiplerine göre yine beş sınıfa indirgenmiş, meşcere sınıflarına ait habitat tiplerinin oranları belirlenmiştir. Bunlar yine 2,5 km yarıçaplı kurtların kullandığ 1 habitatların oranlarıyla kıyaslanarak kurtların habitat seçimleri tespit edilmiştir.

Çalışma alanı içerisinde kurt varlığı tespit edilen noktalar ve rastgele atılan noktaların deniz seviyesinden yükseklik değerleri her bir nokta için ayrı ayrı kaydedilmiş ve beş sınıfa ayrılarak t-testi ile analiz edilmiştir. Bakı sınıfları 4 sınıf (Kuzey, Doğu, Güney, Batı) olacak şekilde ayrılmıştır. Çalışma alanında eğim değeri derece olarak 0 ile 89 derece arasındadır. Dokuz eğim sınıfı 0-10,10-20, 20-30, 30-40, 40-50, 50-60, 60-70- 70-80 ve 8090 olacak şekilde sınıflandırılmıştır. Bu sınıflarla rastgele noktaların sınıflarının aynı aralıkta olup olmadığ $\mathrm{t}$-testi ile karşılaştırılmıştır.

Noktaların en yakın yerleşim yerlerine ve otoyollara uzaklıklarını belirlemek için Google Earth programı kullanılmıştır. Noktalar bu programa aktarılmış ve 'cetvel' sekmesi yardımıyla ölçülmüş ve kaydedilmiştir. Daha sonra bunların ortalama uzaklıkları ve dağılımları yine t-testi kullanılarak birbirinden farklı olup olmadığı, bir tercihin olup olmadığ 1 tespit edilmiştir.

\section{Bulgular}

Yapılan arazi çalışmaları sonucunda kurtlar deniz seviyesinden $535 \mathrm{~m}$ ile 1.855 metreleri arasında ortalama olarak $1.196 \pm 53$ m yükseklikte, çoğunlukla 1.100 m üzerinde kaydedilmiştir (\% 70). Ormanc1lık faaliyetlerinin (kesim, sürütme vb.) devam ettiği hiçbir alanda kurt varlığı tespit edilememiştir. Kurtlar, bulundukları noktaların yüksekliği açısından değerlendirildiğinde örneklerin \% 85'i
800-1.900 m arasında tespit edilmiştir. Kurtların bulunduğu bakılar ile nokta sayısı uyuşum testi ile hesaplandığında istatiksel olarak farklılık tespit edilmiştir (Ki kare $=12,5 ; \mathrm{p}=0,006 ; \mathrm{p}=\leq 0,01)$. Ayrıca kurtların kullandığı noktalar t-testi ile rastgele noktalar ile karşılaştırıldığında $(\mathrm{t}=1,88$; $\mathrm{p}=0,031469$ ) sonuçlarda $\mathrm{p}<0,05$ 'e göre anlamlı fark tespit edilmiştir, ancak bunun örnek büyüklüğünün etkisi sınırlıdır (Gates' delta =0,416). Kurtların en yoğun olarak $(\mathrm{w}=2,1)$ kuzey bakıları tercih ettikleri ve özellikle doğu-batı bakıları tercih etmedikleri belirlenmiştir.

Ayrıca arazide bulunan kurtlara ait noktalara eşit sayıdaki rastgele seçilen noktalara $(n=48)$ ait 2,5 km yarıçaplı tampon alanlarda potansiyel kulland1ğ alan olarak kaydedilerek mevcut habitat tiplerine ait kullanım oranları belirlenmiştir (Tablo 1).

Ayrica mevcut habitat tipi olarak rastgele noktalar yerine Bolu Orman Bölge Müdürlüğü sınırları içerisinde bulunan 509 farklı meşcereyle ilişkili habitatlar vejetasyon tipine göre beş farklı habitat sınıfına (Yapraklı, İbreli, Karışık, Ziraat-İskân, Orman İçi Açıklık) ayrılarak bunlar kullanılmıştır. Buradan elde edilen oranlar kurtların kullandığ alanların oranlarıyla karşılaştırılmıştır (Tablo 2).

Her iki durum da kurtların seçimi karşılaştırıldığında ibreli ormanların seçimi çoğunluğu teşkil etmektedir (Tablo 1 ve Tablo 2). Bunu karışık ve yaprakl1 ormanlar izlemektedir. Ancak habitat seçimine bakıldığında özellikle ibreli ormanların yüksek düzeyde $(\mathrm{w}=1,35)$, yapraklı ormanların $(\mathrm{w}=1,18)$ ve karışık ormanların $(\mathrm{w}=1,16)$ daha düşük olarak tercih edildiği anlaşılmıştır (Tablo 1). Bununla beraber 0,52 ve 0,71 seçilim oranıyla da kurtların sırasıyla "Ziraat ve İskân" alanları ile "Orman İçi Açıklık" alanlarından uzak kalmayı tercih ettikleri belirlenmiştir (Tablo 1). Bu oran yapılan doğrulama çalışmasında da benzer çıkmıştır (Tablo 2).

Tablo 1: Rastgele tamponlu alanlara ait vejetasyon tipiyle, kurtların bulunduğu alanların meşçerelerinin karşılaştırılması ve seçilim oranları

Table 1. Comparison of vegetation type in randomly chosen areas and the stands in the areas where wolves exist

\begin{tabular}{lccccc}
\hline $\begin{array}{l}\text { Rastgele noktalara ait farklı } \\
\text { habitat tipleri } \\
(2,5 \mathrm{~km} \text { tampon zonlu) }\end{array}$ & $\begin{array}{c}\text { Toplam Alan } \\
\text { büyüklüğ̈̈ } \\
(\text { ha) }\end{array}$ & $\begin{array}{c}\text { Mevcut } \\
\text { bulunma } \\
\text { oranı }\end{array}$ & $\begin{array}{c}\text { Kullanılan } \\
\text { alan } \\
\text { büyüklüğü } \\
\text { (ha) }\end{array}$ & $\begin{array}{c}\text { Kullanılan } \\
\text { oran }\end{array}$ & $\begin{array}{c}\text { w= habitat } \\
\text { seçim oranı }\end{array}$ \\
\hline İbreli ormanlar & 28.491 & 0,30 & 38.560 & 0,41 & 1,35 \\
Yapraklı ormanlar & 14.730 & 0,16 & 17.451 & 0,19 & 1,18 \\
Karışı ormanlar & 15.413 & 0,16 & 17.888 & 0,19 & 1,16 \\
Ziraat -İskan & 25.914 & 0,27 & 13.505 & 0,14 & 0,52 \\
O.İ.A.A & 9.700 & 0,10 & 6.844 & 0,07 & 0,71 \\
\hline
\end{tabular}


$\mathrm{Bu}$ tercih oranları tüm Bölge Müdürlüğü’ndeki vejetasyon tipleri ile karşılaştırınca yine ibreli ormanların 1,22 seçim faktörü ile seçildiğine ancak karışık ormanların daha çok tercih edilebileceği 1,33'le ortaya konmuştur (Tablo 2). En düşük seçim burada yapraklı ormanlar içindir $(\mathrm{w}=1,11)$. Yine aynı şekilde Ziraat ve İskân alanları ile Orman İçi Açıklık alanlardan uzak kalmayı tercih etmektedirler.

Tablo 2: Bolu Orman Bölge Müdürlüğündeki tüm alanlara ait vejetasyon tipiyle, kurtların bulunduğu tamponlu alanların oranlarının karşılaştırılması ve seçim oranları

Table 2. Comparison of vegetation types of all areas in Bolu Regional Directorate of Forestry and the proportions of the buffered areas where wolves are present, and the selection rates

\begin{tabular}{lccc}
\hline $\begin{array}{l}\text { Bolu Orman } \\
\text { Bölge Müd. } \\
\text { Habitat Sınıfları }\end{array}$ & $\begin{array}{c}\text { Mevcut } \\
\text { oran }\end{array}$ & $\begin{array}{c}\text { Kullanılan } \\
\text { oran }\end{array}$ & $\begin{array}{c}\text { w=seçim } \\
\text { oranı }\end{array}$ \\
\hline $\begin{array}{l}\text { İbreli ormanlar } \\
\begin{array}{l}\text { Yapraklı } \\
\text { ormanlar }\end{array}\end{array}$ & 0,335 & 0,41 & 1,22 \\
$\begin{array}{l}\text { Karışı } \\
\text { ormanlar }\end{array}$ & 0,167 & 0,19 & 1,11 \\
$\begin{array}{l}\text { Ziraat -İskan } \\
\text { O.I.A.A }\end{array}$ & 0,267 & 0,14 & 0,54 \\
\hline
\end{tabular}

Kurtların yerleşim yerlerine ortalama olarak $2.207 \pm 256 \mathrm{~m}$ ve otoyollara $5.539 \pm 827 \mathrm{~m}$ uzaklıklarda varlık gösterdiği belirlenmiştir. Rastgele noktalar ise ortalama olarak $1.588 \pm 314 \mathrm{~m}$ ile $3.006 \pm 408 \mathrm{~m}$ aralıklarında yer almıştır. Kullanılan noktaların yerleşim yerleri ve otoyollara olan uzaklıkları karşılaştırıldığında yerleşim yerleriyle rastgele noktalar arasında anlamlı bir fark çıkmamıştır ancak kurtların otoyollardan daha uzak alanları tercih ettikleri belirlenmiştir ( $\mathrm{t}$-değeri $=-2,74774$; $\mathrm{p}=0,0036$ ). Örnek nokta sayısının sonuca etki büyüklüğü hesaplandığında Gates' delta $=0,9$ oranında etkili çıkmıştır.

Eğim sınıfları açısından veriler incelendiğinde kurtların \% 75'inin 50 ve 80 derece arasındaki eğimlerde bulunduğu tespit edilmiştir. Ancak kurtların belli eğimleri tercih edip etmediği hususunda düşük bir seçilim oranıyla $(\mathrm{w}=1,05)$, bu aralığ 1 tercih ettiği, 60-70 derece arasını ise $\mathrm{W}=1,16$ gibi bir seçim oranı ile tercih ettiği belirlenmiştir. İstatiksel olarak eğim seçiminde anlamsal bir farklılık tespit edilememiştir.

\section{Tartışma ve Sonuç}

Yapılan çalışmada kurtların bulunduğu habitatların rastgele noktalarla karşılaştırılması sonucu daha çok ibreli ormanları, ardından yapraklı ve karışık ormanlarını tercih ettiği tespit edilmiştir. Ancak özellikle Ziraat-İskân alanlarından ve Orman İçi Açıklıklar başta olmak üzere yollardan uzak alanları tercih ettiği tespit edilmiştir. Ayrıca deniz seviyesinin genelde 800 metre üzerinde bulundukları, kuzey bakıları daha çok tercih ettikleri ve genellikle 50 derece üzerinde eğimli arazilerde bulundukları, otoyollardan daha uzak alanları tercih ettikleri tespit edilmiştir.

Çalışma alanı sınırları içerinde kalan Düzce ilinde yapılan Biyoçeşitlilik Envanteri Çalışmasında (Keten, 2016) yırtıcıların daha çok yapraklı ormanlık alanları tercih ettiklerini belirlenmiştir. Yapılan çalışmada Bolu ilinin de olması nedeniyle tüm alanda yapraklıların ikinci sırada tercih edildiği belirlenmiştir. Ayrıca çalışma alanı içerisinde bulunan ve yüzeysel olarak Düzce ilinden büyük olan Bolu ilinin ormanlarının büyük ölçüde ibreli olması (Anonim, 2012) veya yapılan çalışmanın birden fazla türde olması nedeniyle sonuçlarda farklılık yarattığı düşünülmektedir.

Ülkemizde kurtlar üzerinde yapılan habitat uygunluk modeli çalışmasında, kurtların habitat tercihlerinde deniz seviyesinden yükseklik etkisinin önemli olduğu ve yükseklik arttıkça kurtların yayılışının arttığ1, ormanlık alanlardan uzaklaştıkça bulunma olasılığının azaldığ 1 ve yerleşim yeri ve otoyollara uzaklığın göz ardı edilebileceği belirtilmiştir (Ertürk, 2010). Çalışma alanı içerinde ise kurtların özellikle yerleşim yerlerinden ve otoyollardan uzak alanları tercih ettiği belirlenmiştir. $\mathrm{Bu}$ durum büyük ölçüde E-80 ve D100 gibi Türkiye'deki en yoğun kullanılan otoyollarla daha küçük ölçekteki yolların yaban hayatına etkisi olarak düşünülmektedir. Bu kapsamda Batı Karadeniz Ormancılık Araştırma Müdürlügü’nün yürüttüğü Yolların Yaban Hayatına Etkisi Projesi de büyük etçil ve otçul türlerin bu yollardan nasıl etkilendiğini ortaya koymaya başlamıştır. Alanda trafik kazası sonucu birçok ölü hayvan bulunmuştur (Örneğin Çaydurt civarında trafik kazası sonucu ölmüş bir kurt). Kurtların daha önceden yapılan çalışmalarda yerleşim yerleri veya insan faaliyetlerinin yoğun olduğu bölgelerden kaçındıkları (Mladenoff ve ark., 1995; Massolo ve Meriggi, 1998; Jedrzejewski ve ark., 2004) ve ormanlık alanları tercih ettikleri belirlenmiştir (Massolo ve Meriggi, 1998; Zlatonova ve Popova, 2013; Jedrzejewski ve ark., 2004). Çalışmamızda da ziraat alanları genellikle yerleşim yerlerin etrafında toplandığından, yerleşim 
yerlerini tercih etmekten kaçındıkları (McLoughlin ve ark., 2004) için bu gibi yerleri de tercih etmedikleri görülmüştür. Bulgaristan'da yapılan bir çalışmada kurtların otoyollara yakın yerlerde bulunmaktan sakındıkları ve deniz seviyesinden oldukça yüksek bölgeleri tercih ettikleri (Zlatonova ve Popova, 2013) yaptığımız çalışmaya benzer sonuçlar ortaya koymaktadır.

$\mathrm{Bu}$ çalışmada da benzer sonucun bulunmasının nedeninin; kurtların insanlarla karşılaşma olasıl1ğının deniz seviyesinden yüksek bölgelerde alçak bölgelere nazaran daha az olması olduğu düşünülmektedir. Bu durum başka araştırmacılar tarafından da gösterilmiştir (Massolo ve Meriggi, 1998). Ülkemiz dışında yapılan bu çalışmalar ülkemiz sonuçları ile benzer nitelikte olup kurtların gerçekten otoyollardan sakındıklarını, ormanlık alanları ve deniz seviyesinden yüksek yerleri tercih ettiklerini ortaya koymaktadır.

Ayrıca Milakoviç ve ark.'in (2011) yaptığı çalışmada kurtların kuzey yönlerini tercih etmekten kaçındığ 1 batı yönlerini tercih etme eğilimde oldukları belirlenmiştir. Bu durumun nedeni kurtların çok sık ibreli orman yönünden kaçındıkları ile açıklanmıştır ve kurtların vejetasyon durumu ile yön seçiliminde ters bir ilişki olduğunu ortaya koymaktadır. Bizim çalışma alanımızda ise muhtemelen ormanlardaki işletme faaliyetlerinin yoğunluğuna göre bunların da değişebileceği göz önünde bulundurulmalıdır. 2017 yılında özellikle Bolu Orman Bölge Müdürlüğü İşletme Müdürlüklerine bağlı yoğun ormancılık faaliyetleri yürütülmüştür. $\mathrm{Bu}$ faaliyetler de yabani hayvanların habitat tercihlerini etkilemekte ve optimum habitatlardan daha az verimli habitatlara doğru gitme zorunluluğu doğurmaktadır (Oğurlu, 2001).

Orman vejetasyon tipleri bakımından ülkemiz d1şında yapılan diğer bir çalışmada ibreli ve karışık ormanların daha çok tercih edildiği (Arjo ve Peltscher, 2004) belirtilmiş ve bunun nedeninin kurtlar için potansiyel av türlerini oluşturan otçulların bu alanlarda daha çok varlık göstermesi olduğu ortaya konulmuştur (Jedrzejewski ve ark., 2004). Ormancılık faaliyetlerinin kurtların yaşam alanları üzerinde ve habitat tercihleri açısından olumsuz etkisi vardır ve kurtların kesim sahalarından kaçındıkları bilinmektedir (Kuzyk ve ark.,2004). Yapılan arazi çalışmaları sırasında özellikle üretim yapılan kesim sahalarının yakınlarında kurt varlığ 1 hiç tespit edilememiştir ve yukarıdaki görüş büyük oranda desteklenmiştir. Bu nedenle ormancılık faaliyetlerinin kurtların üreme ve yavru büyütme mevsimleri dışında bir zamanda, olabildiğince hızlı ve doğal tahribata sebep olmadan yapılması gerekmektedir.
Kurtların insan alanlarından uzakta olduklarına ilişkin en iyi doğrulama çalışmalarından bir tanesi de diyet tercihleridir. Ülkemizde kurtların diyeti ile ilgili az sayıda çalışma (Buzbaş, 2002; Capitani ve ark., 2015) bulunmaktadır. Burada sözü edilen çalışma alanında ise böyle bir çalışma mevcut değildir. Kurtların bu bölgelerdeki besin tercihini ve kurt-insan çatışması boyutunu belirlemek için diyet çalışmaları yapılması gerekmektedir. Bu nedenle çalışmamızın devamında kurtların diyetleri ve daha çok hangi av türlerini tercih ettikleri ortaya konacaktır.

Ekolojik ve biyolojik parametrelerin de daha iyi elde edilmesi için kurtlara GPS-GSM'li veya UHF'li verici sistemleri takılarak inceleme yapılmasının oldukça yararlı olacağı düşünülmektedir.

\section{Teşekkür}

$\mathrm{Bu}$ çalışma için arazi aracı desteği sağlayan ve kurtların konum verilerini paylaşan Dr. Akif KETEN'e teşekkür ederiz.

\section{Kaynaklar}

Ambarl1, H., Ertürk, A., Soyumert, A., 2016. Current status, distribution and conservation of brown bear (Ursidae) and wild canids (gray wolf, golden jackal and red fox; Canidae) in Turkey. Turkish Journal of Zoology 40: 944-956.

Anonim, 2018a. Meteoroloji Genel Müdürlüğü. https:// www.mgm.gov.tr/veridegerlendirme/il-ve-ilceler-istatistik.aspx?m=DUZCE (Erişim Tarihi: 13.04.2018)

Anonim, 2018b. Meteoroloji Genel Müdürlüğü. https:// www.mgm.gov.tr/veridegerlendirme/il-ve-ilceler-istatistik.aspx?m=BOLU (Erişim Tarihi: 13.04.2018)

Anonim, 2012. Bolu Orman Bölge Müdürlüğü 2012 Birim Faaliyet Raporu. https://boluobm.ogm.gov.tr/ FaaliyetRaporu/Bolu\%20Orman\%20B\%C3\%B6lge\%20 $\mathrm{M} \% \mathrm{C} 3 \% \mathrm{BCd} \% \mathrm{C} 3 \% \mathrm{BCrl} \% \mathrm{C} 3 \% \mathrm{BC} \% \mathrm{C} 4 \% 9 \mathrm{~F} \% \mathrm{C} 3 \%$ BC\%202012\%20Y\%C4\%B11\%C4\%B1\%20Birim\%20 Faaliyet\%20Raporu.pdf (Erişim Tarihi: 13.04.2018)

Arjo, W.M., Pletscher, H.D., 2004. Coyote and Wolf Use in Northwestern Montana, USDA National Wildlife Research Center - Staff Puplications.71.

Buzbaş, E.Ö., 2002. Activity, abundance and diet of the gray wolf (Canis lupus) in eastern Thrace, Turkey. Yüksek lisans tezi, Boğaziçi Üniversitesi, İstanbul, Türkiye, $71 \mathrm{~s}$.

Can, Ö.E., 2001. The Status of gray wolf (Canis lupus L. 1758) brown bear (Ursus arctos L. 1758) and Eurasian lynx (Lynx lynx 1758) in Turkey and recommendation for effective conservation programs, Yüksek Lisans Tezi, Orta Doğu Teknik Üniversitesi, Ankara, Türkiye. 109s. 
Capitani, C., Chynoweth, M., Kusak, J., Çoban, E. and Şekercioğlu, Ç., 2015. Wolf diet in an agricultural landscape of nort-eastern Turkey. Mammalia 80 (3):1-6

Ertürk, A., 2010. GIS based Canis lupus L. 1758 (Carnivora:Canidae) (gray wolf) habitat suitability analysis and modelling species distribution in Bartin province, Yüksek Lisans Tezi, Hacettepe Üniversitesi, Ankara, Türkiye, 92s.

Ertürk, A., 2017. Research on the spatial ecology and population structure of Anatolian Canis lupus L. 1758 (gray wolf), Doktora Tezi, Hacettepe Üniversitesi. Ankara, Türkiye. 248s.

Jedrzejewski, W., Niedzilkowska, M., Nowak, S., Jedrzejewska, B., 2004. Habitat variables associated with wolf (Canis lupus) distribution and abundance in northern Poland. Diversity and Distributions 10: 225-233.

Keten, A., 2016. Düzce İlinde Yırtıcı Memeli Türlerin Zamansal ve Mekânsal Dağılımı. Kastamonu Üniv., Orman Fakültesi Dergisi. 16(2):566-574.

Kuzyk G.W., Kneteman, J. and Schemiegelow, F.K.A., 2004. Winter habitat use by Wolves, Canis lupus, in relation to forest harvesting in west-central Alberta. $\mathrm{Ca}$ nadian Field-Naturalist 118(3): 368-375.

Manly, B.F.L., McDonald, L.L., Thomas, D.L., McDonald, T.L., Erickson, WP., 2002. Resource Selection by Animals: Statistical Design and Analysis for Field Studies $2^{\text {nd }}$ edn. Dordrecht - The Netherlands: Kluwer Academic.

Massolo, A., Meriggi, A., 1998. Factors affecting habitat occupancy by wolves in northen Apennines (northern Italy): a model of habitat suitability. Ecography 21:97107.

McLoughlin, P.D., Walton, L.R., Cluff, H.D., Paquet, P.C. and Ramsay, M.A., 2004. Hierarchical habitat selection by tundra wolves. Journal of Mammalogy 85(3):576-580.

Mech, L.D. and L. Boitani., 2003. Wolves: Behavior, ecology and conservation. University of Chicago, Chicago.

Mech, L.D., 1996. A new era for carnivore conservation. Wildlife Society Bulletin 24(3):397-401.

Merrill, S.B., Mech, D., 2000. Details of Extensive Movements by Minnesota Wolves (Canis lupus). The American Midland Naturalist. 144(2):428-433.

Milakoviç, B., Parker, K.L., Gustine, D.D., Lay, R.J., Walker, A.B.D. and Gillingham, M.P., 2011. Habitat selection by a focal predator (Canis lupus) in a multiprey ecosystem of the northern Rockies. Journal of Mamma$\log y$ 92(3):568-582.

Mladenoff, D.J., Sickley, A.T., Haight, R.G., Wydeven P.A., 1995. A Regional Landscape Analysis and Prediction of Favorable Gray Wolf Habitat in the Northern Greet Lekes Region. Conservation Biology. 9(2):279-294.

Oğurlu, İ., 2001. Yaban Hayatı Ekolojisi, Süleyman Demirel Üniversitesi Orman Fakültesi Yayınları, Orman Fakültesi Yayını, Türkiye.

Tuğ, S., 2005. Conflicts between humans and wolf: A study in Bozdağ, Konya province, Turkey, Yüksek Lisans Tezi, Orta Doğu Teknik Üniversitesi. Ankara, Türkiye. $58 \mathrm{~s}$.

Wagner, C., Holzapfel, M., Reinhardt, I., Ansorge, Hermann., 2012. Wolf (Canis lupus) feeding habits during the first eight years of its occurrence in Germany, Mammalian Biology 77: 196-203.

Zlatonova, D., Popova, E., 2013. Habitat variables associated with wolf (Canis lupus) distribution and abundance in Bulgaria. Bulgaria Journal of Agricultural Science 19(2), 262-266. 